\title{
Valuing Florida Water Resources: Water Use in Irrigated Agriculture ${ }^{1}$
}

\author{
Tatiana Borisova, Syed Irfan Ali Shah, Tara Wade, Kelly Grogan, and Xiang Bi ${ }^{2}$
}

\section{Introduction}

This paper is a part of the series "Economic Value of Florida Water Resources." Water resources provide us with a variety of goods and services (together often referred to as "ecosystem services" or "environmental services"). The overall goal of this and other publications in this series is to discuss the economic assessments of the value of the ecosystem services, and to show the importance of water resource protection and restoration. Readers can select the economic value estimates that are most relevant for a given geographic area or type of water use.

Irrigation for agriculture is one example of an ecosystem service provided by water resources (other papers in this series discuss other ecosystem services, such as tap water supply, recreation, and amenity value for waterfront properties). Many of the fruits and vegetables in grocery stores are produced in Florida, and yields for many of them depend on access to irrigation water. In 2015, 47,300 commercial farms and ranches operated in Florida covering over 9.45 million acres (FDACS 2015). Irrigated crops were about 24 percent, or just under 2 million acres, an area roughly equal to the state of Delaware. Favorable climate and access to water allow Florida to be a leader in production value of many crops (Table 1). For example, Florida is the first in the nation in the production value of oranges, fresh market tomatoes, watermelons, grapefruit, sugarcane, fresh market snap beans, and fresh market cucumbers. Florida is ranked second in the United States in the value of greenhouse and nursery products, as well as such fruits and vegetables as bell peppers, strawberries, fresh market sweet corn, spring potatoes, peanuts, tangerines, and avocados. Florida ranked seventh in the country for agricultural exports, with over \$4 billion of agriculture commodities shipped in 2015 (FDACS 2015). As mentioned above, access to water for irrigation is key for production of many of these crops in Florida.

Table 1. Total production value of Florida products-2015 (FDACS 2015).

\begin{tabular}{|l|c|l|}
\hline \multicolumn{1}{|c|}{ Product } & \% US value & \multicolumn{1}{c|}{ Value in dollars } \\
\hline Oranges & $60 \%$ & \$1.17 billion \\
\hline Grapefruit & $58 \%$ & $\$ 117$ million \\
\hline Sugarcane for sugar and seed & $54 \%$ & $\$ 515$ million \\
\hline Fresh cucumbers & $37 \%$ & $\$ 64.4$ million \\
\hline Fresh market tomatoes & $36 \%$ & $\$ 453$ million \\
\hline Snap beans & $32 \%$ & $\$ 76.3$ million \\
\hline Bell peppers & $27 \%$ & $\$ 220$ million \\
\hline Sweet corn & $23 \%$ & $\$ 155$ million \\
\hline Watermelon & $18 \%$ & $\$ 88.2$ million \\
\hline
\end{tabular}

Agriculture is the second largest freshwater use category in Florida (after public supply), accounting for 2,089 Mgal/d of freshwater withdrawal in 2015 (Marella and Dixon 2018), with the major Florida crops accounting for a large share of

1. This document is FE1057, one of a series of the Food and Resource Economics Department, UF/IFAS Extension. Original publication date April 2019. Visit the EDIS website at https://edis.ifas.ufl.edu for the currently supported version of this publication.

2. Tatiana Borisova, assistant professor and Extension specialist, Food and Resource Economics Department; Syed Irfan Ali Shah, project assistant, Food and Resource Economics Department; Tara Wade, assistant professor, Food and Resource Economics Department, UF/IFAS Southwest Florida Research and Education Center; Kelly Grogan, associate professor, Food and Resource Economics Department; and Xiang Bi, assistant professor, Food and Resource Economics Department; UF/IFAS Extension, Gainesville, FL 32611.

The Institute of Food and Agricultural Sciences (IFAS) is an Equal Opportunity Institution authorized to provide research, educational information and other services only to individuals and institutions that function with non-discrimination with respect to race, creed, color, religion, age, disability, sex, sexual orientation, marital status, national origin, political opinions or affiliations. For more information on obtaining other UF/IFAS Extension publications, contact your county's UF/IFAS Extension office. 
agricultural water use (Figure 1). How is agricultural irrigation water use related to the value of agricultural products? What is the value of water in agricultural use? Three studies were found that examine the effect of water use change on agriculture in Florida and Georgia. The studies employ different estimation methods and data; however, their estimates of the water values are relatively close.

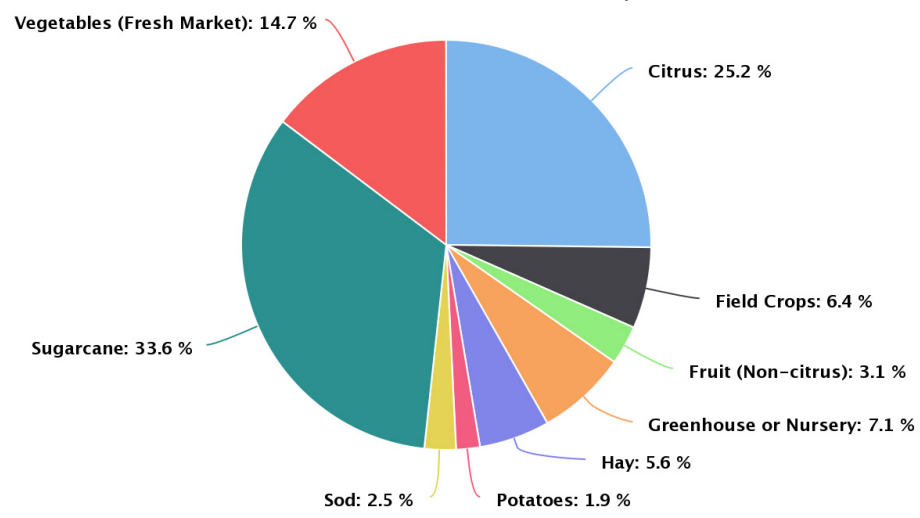

Figure 1. Percent of 2015 agricultural water usage in Florida, by crops. Credits: FDACS (2018)

\section{The Value of Water for Florida Agriculture: Results from a Nationwide Study}

DeBodisco (2007) examined the value of irrigation water across US regions, including the 20 largest irrigation states. This study developed a statistical model of agricultural profits (estimated on a per-acre basis) by accounting for a wide range of profit determinants (such as types of crops and their sale prices; labor, fuel, machinery, and chemical costs; soil, climate, water supply, and irrigation technologies). The value of water is then estimated as the change in profits for a given change in water use.

For Florida, the estimated change in agricultural profit (i.e., the value of water for agriculture) was $\$ 11.49$ for 0.1 acre- $\mathrm{ft}$ of water (estimated for the statewide average level of water use of 0.69 acre- $\mathrm{ft}$ per acre). Assuming the water value was estimated for mid-2007 (when the study was completed), and accounting for inflation using the consumer price index (BLS 2018), the estimated average statewide value of irrigation water for Florida agriculture is $\$ 13.90$ for 0.1 acre-ft (in mid-2018 dollars). Note that the value can be higher or lower in specific Florida regions based on the value of crops produced, soil quality, etc.; however, these details were not explored given the national scope of this study.

\section{Value of Irrigation Water in Cropland Farming: South Florida Case Study}

Takatsuka et al. (2018) examined variation in the value of irrigation water among regions in south Florida. The methodology employed in this study differs from DeBodisco (2007). Specifically, the study did not have access to data on all the production costs, and, therefore, it focused on "economic penalties" for changes in water use, rather than the profit reduction analyzed in DeBodisco (2007). A model was developed to relate the value of farm cropland products sold in each region (in \$) to the share of irrigated and fertilized land in each region, employment in cropland (number of full-time equivalent), and groundwater and/ or surface water use in cropland (acre-ft/year). This model then was used to assess the economic penalties for changes in surface or groundwater use. Economic penalty is defined in this article as the change in the value of farm cropland products sold (\$) after accounting for the changes in water pumping costs. Note that the study did not account for cost of agricultural inputs except water (due to the lack of data), and therefore, the economic penalty is not the same as changes in agricultural profits assessed in DeBodisco (2007).

Overall, the Takatsuka et al. study shows that reduction in agricultural water use in the jurisdiction of the South Florida Water Management District (SFWMD) can significantly impact the agricultural economy. It also shows wide variations in the economic penalties, from $\$ 0.07$ to $\$ 518.56$ per 0.1 acre-ft per year per acre. Following SFWMD's water supply planning, the study divides the District into four regions: 1) Kissimmee Basin; 2) Lower East Coast; 3) Lower West Coast; and 4) Upper East Coast, with each region further sub-divided into counties or portions of counties (Figure 2). The water-use data were analyzed for 2000, 2005, and 2010.

Table 2 shows the estimated economic penalties associated with surface or groundwater water-use reduction in cropland irrigation in each sub-region. On a regional level, because many regions largely depend on groundwater, the estimated results show higher economic penalties given groundwater-use reduction, as compared with surface-water use reduction. The difference in the economic penalties among sub-regions is related to variations in the values of crops produced, with counties producing higher-valued crops generally showing higher value for water use. 


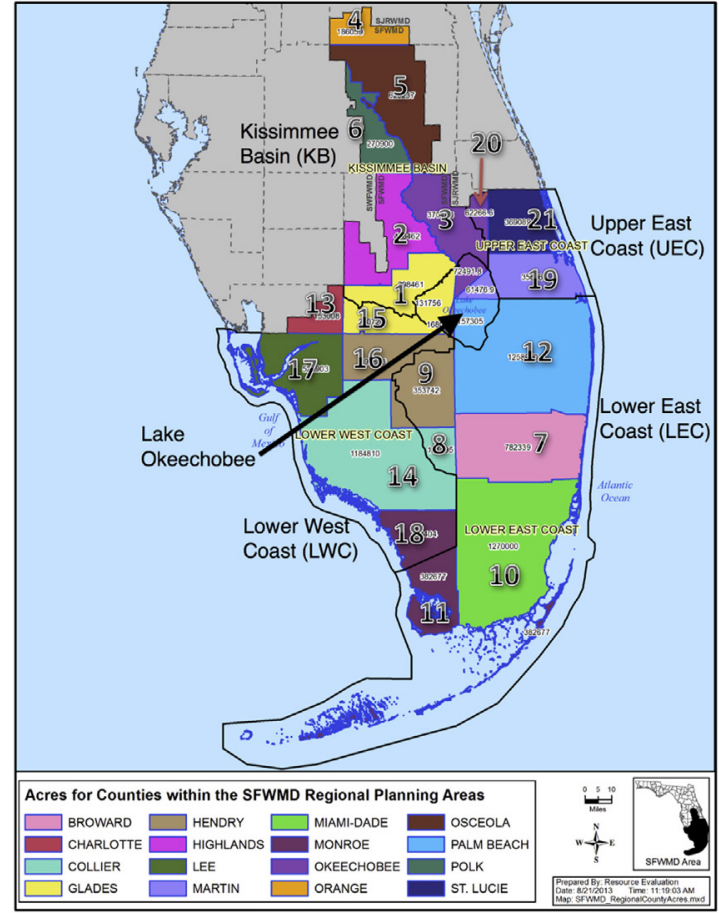

Figure 2. SFWMD map and area number.

Credits: Takatsuka et al. (2018)

Generally, the study shows that reduction in water use can result in significant reduction in the value of crops produced. For example, in the portion of Orange County within Kissimmee Basin, if groundwater use is reduced by 1000 acre-ft per year, the cropland farming value drops by almost 2.9 million (even after considering the reductions in water pumping costs due to the water-use cuts). Cropland farming crop value losses are also above $\$ 1$ million in Polk and Broward Counties (again, after taking into consideration the drop in pumping cost due to water-use reduction). For surface-water use, 1000 acre-ft/year reduction results in approximately $\$ 0.5$ million economic penalties in portions of the Lower East Coast region in Collier and Miami-Dade counties, as well as in Osceola County (in the Kissimmee Basin). Note that Table 2 reports estimates for 1000 acre-ft per year, and the losses will be higher for a more sizable reduction in water use.

The per-acre analysis shows that the economic penalty is the highest for Miami-Dade County for surface-water-use reduction: 0.1 acre-ft/year per acre water-use reduction is estimated to lead to $\$ 518.56 /$ acre economic penalty (Table $2)$. The penalty is the lowest for Glades County ( $\$ 0.07 /$ acre). The median value for surface water among the regions is $\$ 0.91$ / acre for 0.1 acre-ft/year per acre, or $\$ 0.91$ for 0.1 acre- $\mathrm{ft} /$ year. The median value for groundwater is $\$ 4.75$ / acre for 0.1 acre-ft/year per acre, or $\$ 4.75$ for 0.1 acre-ft/ year.

\section{The Value of Agricultural Water Use Permits: South Georgia Case Study}

Petrie and Taylor (2007) is a study conducted just north of Florida's border in Dooly County, Georgia. The study compared the price of agricultural land parcels sold from 1993 to 2003, accounting for whether the parcels had water use permits attached to them or not, as well as other land characteristics. This method of comparing sales to analyze the effects on sale prices of such property characteristics as size, soil quality, conservation use, share of the property dedicated to crops or woodland, and access to irrigation permit is called the "hedonic method."

Dooly County was the largest producer of cotton in Georgia and also a leading producer of wheat. Peanuts and soybeans were important crops for the county as well. In other words, agricultural crops were somewhat similar to those produced in the Florida panhandle. Focusing on Dooly County allowed the authors to explore the effect of a particular agricultural water-use restriction, a moratorium, because the moratorium affected some but not all areas of the county. The moratorium was imposed on the issuance of agricultural water-use permits in the Flint River Basin in 1999 in response to a drought, growing water demand for public supply and agriculture, and litigations between Florida and Alabama. The permits were still required for any water use in excess of 100,000 gallons of water a day. The right of existing water-permit holders to irrigate was respected. The permits were attached to the land, and if a land parcel with an existing permit was sold, the permit was transferred to the new landowner. Landowners without permits were allowed to dryland crop or to irrigate less than 100,000 gallons a day. Approximately half of Dooly County was in the Flint River Basin, and affected by the moratorium; the other half was not, which allowed for a comparison of sale prices to explore the effects of the moratorium.

The sale price of agricultural land reflects the value of future profits expected from that land (discounted to reflect the fact that the future profits are valued less than the current profits). Even after the study accounted for various land characteristics (such as soil quality, designation for recreational uses, woodland and timberland shares, and price of the structures on the land), access to a water-use permit still had a statistically significant effect on the land sale price, reflecting the dependence of the future profits on the access to a water-use permit. For productive agricultural acreage, land with a permit was sold for 
approximately $\$ 500 /$ acre more than land with no permit (and therefore limited irrigation allowed). The median sale price of an acre during the study period was $\$ 1,500$ (in 2003 dollars), and, therefore, approximately a 30\% increase in property values was associated with an irrigation permit granted to the parcel. The authors translated this estimate into approximately $\$ 3.54$ for 0.1 acre- $\mathrm{ft}$ of water per year (in 2003 dollars; assuming 30-year planning horizon and annual average irrigation needs of 0.7 acre-feet per acre). After accounting for inflation (using consumer price index for mid-2003 to mid-2018 range (BLS 2018)), this translates into $\$ 4.85$ for 0.1 acre-ft / year. This estimate is generally similar to the results reported by Takatsuka et al. (2018) and described above.

\section{Conclusion}

Three studies estimating the value of water for agricultural irrigation in Florida and Georgia were found and reviewed for this publication. The studies rely on different methodologies and indicators of the value. DeBodisco (2007) examined the change in agricultural profits resulting from changes in agricultural water use, where profit accounts for sale revenue and the cost of production inputs. In turn, Petrie and Taylor (2007) also examined the effect of water use on agricultural profits, but they estimated profits through sale prices of agricultural parcels (which are a reflection of expected future profits from the parcels). While both studies focus on the relationship between agricultural profits and water use, the differences in the estimation methods and geographical scope of the studies (county vs. regional) explain in part the difference in the results.

Further, Takatsuka et al. (2018) examined economic penalty, that is, reduction in revenue (as opposed to the difference in profits). Due to the lack of relevant data, only water-pumping costs were accounted for in the study. Economic penalties are expected to be higher than agricultural profit change because they do not consider reductions in the input costs (other than water) that can potentially offset some of the revenue loss.

Overall, $\$ 13.90$ per 0.1 acre-ft (in 2018 dollars) could be used as a mean value of agricultural irrigation water, based on DeBodisco (2007). Since the statewide value masks some of the important variation among Florida regions, an interested reader can also refer to the study by Takatsuka et al. (2018), that reports the economic penalty (i.e., crop value less pumping costs) ranging from $\$ 0.07$ to $\$ 518.56$ for 0.1 acre- $\mathrm{ft}$ of water use reduction in south Florida croplands, depending on the type of crops grown and surface and groundwater availability. Finally, a reader working in the Florida panhandle may refer to the estimate reported for Dooly County, Georgia (producer of cotton, wheat, peanut, and soybean) that estimated the value of $\$ 4.85$ for 0.1 acre-ft, as well as 30 percent reduction in the value of agricultural land parcels if the parcel is stripped of the right to irrigate more than 100,000 gallon per day.

Note that an important assumption made in these studies is that the current water-use level maximizes the cropland farming profits (given water-resource policy and other possible constraints). The reader should note that new technologies or management approaches could increase water-use efficiency, and, therefore, allow increased profits for the same or lower per-acre agricultural water-use levels in future.

\section{References}

DeBodisco, C. 2007. The Regional Value Of Water In Agriculture. PhD Dissertation, Department of Economics, Vanderbuilt University. Nashville, TN, 136p. https://etd. library.vanderbilt.edu/available/etd-07242007-003333/ unrestricted/debodiscodiss717.pdf

Florida Department of Agriculture and Consumer Services (FDACS). 2015. Florida Agriculture Overview and Statistics. Extracted from http://www.freshfromflorida.com.

Florida Department of Agriculture and Consumer Services (FDACS). 2018. Florida Statewide Agricultural Irrigation Demand (FSAID): Predicting the amounts and spatial distribution of irrigation water use. https://fdacs-fsaid.com/ fsaid4/

Marella, R. L., and J. F. Dixon. 2018. Data tables summarizing the source-specific estimated water withdrawals in Florida by water source, category, county, and water management district, 2015: U.S. Geological Survey data release, https://www.sciencebase.gov/catalog/ item/5a4ce955e4b0d05ee8c4caca

Petrie, R. A., and L. O. Taylor. 2007. "Estimating the Value of Water Use Permits: A Hedonic Approach Applied to Farmland in the Southeastern United States." Land Economics 83(3), 302-318. https://www.jstor.org/stable/27647774

Takatsuka, Y., M. R. Niekus, J. Harrington, S. Feng, D. Watkins, A. Mirchi, H. Nguyen, and M. Sukop. 2018. "Value of irrigation water usage in South Florida agriculture." Science of the Total Environment 626, 486-496. https://www. sciencedirect.com/science/article/pii/S0048969717336732 
U.S. Bureau of Labor Statistics (BLS). 2018. CPI Inflation

Calculator. https://data.bls.gov/cgi-bin/cpicalc.pl? $\operatorname{cost} 1=3.5$

4\&year $1=200307$ \&year $2=201807$

Table 2. Economic penalty (i.e., changes in crop value and pumping cost) for cropland farming associated with water use reduction.

\begin{tabular}{|c|c|c|c|c|c|c|}
\hline \multirow[t]{2}{*}{ Region } & \multirow[t]{2}{*}{ Sub-region } & \multirow[t]{2}{*}{$\begin{array}{l}\text { County within the } \\
\text { sub-region* }\end{array}$} & \multicolumn{2}{|c|}{$\begin{array}{c}\text { Economic penalty } \\
\text { (\$ million) } \\
\text { for } 1000 \text { acre-ft/year water use } \\
\text { reduction in sub-region }\end{array}$} & \multicolumn{2}{|c|}{$\begin{array}{c}\text { Economic penalty } \\
\text { (\$ / acre) } \\
\text { for water use reduction of } 0.1 \\
\text { acre-ft/year per acre }\end{array}$} \\
\hline & & & Surface water & Groundwater & Surface water & Groundwater \\
\hline \multirow[t]{6}{*}{ Kissimmee Basin } & 1 & Glades & 0.0002 & 0.0036 & 0.07 & 1.07 \\
\hline & 2 & Highland & 0.2268 & 0.0104 & $\mathrm{n} / \mathrm{a}$ & 6.48 \\
\hline & 3 & Okeechobee & 0.0145 & 0.0042 & 3.87 & 1.04 \\
\hline & 4 & Orange & $\mathrm{n} / \mathrm{a}$ & 2.8970 & $\mathrm{n} / \mathrm{a}$ & 86.18 \\
\hline & 5 & Osceola & 0.5379 & 0.0076 & 195.86 & 1.44 \\
\hline & 6 & Polk & $\mathrm{n} / \mathrm{a}$ & 2.1942 & $\mathrm{n} / \mathrm{a}$ & $\mathrm{n} / \mathrm{a}$ \\
\hline \multirow[t]{5}{*}{ Lower East Coast } & 7 & Broward & $\mathrm{n} / \mathrm{a}$ & 1.0339 & $\mathrm{n} / \mathrm{a}$ & 21.91 \\
\hline & 8 & Collier & 0.5458 & 0.0066 & 10.60 & 0.19 \\
\hline & 9 & Hendry & 0.0003 & 0.0047 & 0.30 & 4.75 \\
\hline & 10 & Miami-Dade & 0.4507 & 0.0084 & 518.56 & 4.95 \\
\hline & $12^{* *}$ & Palm Beach & 0.0002 & 0.1134 & 0.78 & $\mathrm{n} / \mathrm{a}$ \\
\hline \multirow[t]{5}{*}{ Lower West Coast } & 13 & Charlotte & 0.0097 & 0.1632 & 0.59 & 9.00 \\
\hline & 14 & Collier & 0.0333 & 0.0006 & 10.60 & 0.19 \\
\hline & 15 & Glades & 0.0004 & 0.0055 & 0.07 & 1.00 \\
\hline & 16 & Hendry & 0.0003 & 0.0043 & 0.30 & 5.00 \\
\hline & 17 & Lee & 0.0290 & 0.0028 & 5.94 & 1.00 \\
\hline \multirow[t]{3}{*}{ Upper East Coast } & $19 * *$ & Martin & 0.0021 & 0.3080 & 0.79 & 192.57 \\
\hline & 20 & Okeechobee & 0.1434 & 0.0290 & 3.87 & 1.04 \\
\hline & 21 & St Lucie & 0.0015 & 0.2196 & 0.91 & 301.86 \\
\hline Median*** & & & & & 0.91 & 4.75 \\
\hline
\end{tabular}

